OPEN ACCESS

Edited by:

Mónica Sánchez-Román, Vrije Universiteit Amsterdam,

Netherlands

Reviewed by:

Susan Childers,

Colby College, United States

Magnus Ivarsson,

Swedish Museum of Natural History,

Sweden

Katerina Dontsova

The University of Arizona,

United States

*Correspondence:

Matthew R. M. Izawa

matthew.izawa@gmail.com;

matthew_izawa@okayama-u.ac.jp

†Present address: Lachlan C. W. MacLean, SRK Consulting, Saskatoon, SK,

Canada

Sergei Matveev,

Faculty of Earth and Life Sciences,

Universiteit Utrecht, Utrecht,

Netherlands

Gordon Southam,

School of Earth Sciences,

The University of Queensland,

Brisbane, QLD, Australia

Specialty section:

This article was submitted to

Biogeoscience,

a section of the journal

Frontiers in Earth Science

Received: 22 June 2018

Accepted: 27 May 2019

Published: 14 June 2019

Citation:

Izawa MRM, Dynes JJ,

Banerjee NR, Flemming RL, MacLean LCW, Hetherington CJ,

Matveev S and Southam G (2019)

Organic Matter Preservation

and Incipient Mineralization

of Microtubules in 120 Ma Basaltic

Glass. Front. Earth Sci. 7:149.

doi: 10.3389/feart.2019.00149

\section{Organic Matter Preservation and Incipient Mineralization of Microtubules in 120 Ma Basaltic Glass}

\author{
Matthew R. M. Izawa ${ }^{1,2 *}$, James J. Dynes ${ }^{3}$, Neil R. Banerjee², Roberta L. Flemming ${ }^{2}$, \\ Lachlan C. W. MacLean ${ }^{3 t}$, Callum J. Hetherington ${ }^{4}$, Sergei Matveev ${ }^{5 t}$ and \\ Gordon Southam ${ }^{2 \dagger}$ \\ 1 Institute for Planetary Materials, Okayama University, Okayama, Japan, ${ }^{2}$ Department of Earth Sciences, University \\ of Western Ontario, London, ON, Canada, ${ }^{3}$ Canadian Light Source, Inc., University of Saskatchewan, Saskatoon, SK, \\ Canada, ${ }^{4}$ Department of Geosciences, Texas Tech University, Lubbock, TX, United States, ${ }^{5}$ Department of Earth \\ and Atmospheric Sciences, University of Alberta, Edmonton, AB, Canada
}

Hollow tubular structures in subaqueously-emplaced basaltic glass may represent trace fossils caused by microbially-mediated glass dissolution. Mineralized structures of similar morphology and spatial distribution in ancient, metamorphosed basaltic rocks have widely been interpreted as ichnofossils, possibly dating to $\sim 3.5 \mathrm{Ga}$ or greater. Doubts have been raised, however, regarding the biogenicity of the original hollow tubules and granules in basaltic glass. In particular, although elevated levels of biologically-important elements such as $\mathrm{C}, \mathrm{S}, \mathrm{N}$, and $\mathrm{P}$ as well as organic compounds have been detected in association with these structures, a direct detection of unambiguously biogenic organic molecules has not been accomplished. In this study, we describe the direct detection of proteins associated with tubular textures in basaltic glass using synchrotron X-ray spectromicroscopy. Protein-rich organic matter is shown to be associated with the margins of hollow and partly-mineralized tubules. Furthermore, a variety of tubule-infilling secondary minerals, including Ti-rich oxide phases, were observed filling and preserving the microtextures, demonstrating a mechanism whereby cellular materials may be preserved through geologic time.

Keywords: ichnofossils, biomolecule, basaltic glass, synchrotron XANES, Ontong Java Plateau

\section{INTRODUCTION}

Hollow or partly-mineralized micron-scale tubular structures in seafloor basaltic glass have been interpreted as trace fossils created by microbially-mediated glass dissolution (Banerjee and Muehlenbachs, 2003; Benzerara et al., 2007; McLoughlin et al., 2008; Cousins et al., 2009; Staudigel et al., 2015). Mineralized structures containing titanite $\left(\mathrm{CaTiSiO}_{5}\right)$, of similar morphology and spatial distribution observed in ancient, metamorphosed basaltic rocks have been interpreted as ichnofossils, possibly dating to $\sim 3.5 \mathrm{Ga}$ or older - making them among the most ancient putative microfossils (Furnes et al., 2004; Banerjee et al., 2007; Staudigel et al., 2008a, 2015).

Basaltic glasses are a common constituent of the Earth's seafloor in the form of pillow rims, hyaloclastites, and volcaniclastic debris. Basaltic glasses can also form in subglacial eruptions or by impact melting of basaltic target rocks. Basaltic glasses are widely distributed in the solar system in space and time, and thus represent an important habitat on early Earth, Mars, and elsewhere (Izawa et al., 2010b). Alteration of basaltic glasses influences the cycling of numerous elements between 
the Earth's hydrosphere, lithosphere, and biosphere (Staudigel and Hart, 1983; Furnes et al., 2001). Early suggestions of a role of microbial alteration in basaltic glass weathering (Jones and Goodbody, 1982; Ross and Fisher, 1986) led to the suggestion that colonizing microbes may cause local variations on $\mathrm{pH}$ that allow them to chemically "drill" into a silicate substrate (Thorseth et al., 1992). Subsequently, multiple lines of evidence were uncovered to support an important role of biology in the alteration of submarine basaltic glass, including isotopically light carbon from carbonates in pillow basalt rims compared to their crystalline cores (e.g., Banerjee and Muehlenbachs, 2003), the presence of carbonaceous materials (Benzerara et al., 2007; Wacey et al., 2014), fluorescence staining indicating the presence of nucleic acids (Banerjee and Muehlenbachs, 2003), and in the form of hollow, micron-scale tubular and granular structures associated with surfaces and fractures (Thorseth et al., 1995b; Torsvik et al., 1998; Furnes et al., 2001; Furnes and Muehlenbachs, 2003; Staudigel et al., 2006; McLoughlin et al., 2008, 2009; Santelli et al., 2008). Tubular textures in particular display morphologies including spirals, segmentation, and branching that are highly suggestive of a biological origin (McLoughlin et al., 2009). It has been hypothesized that microbes enhance the dissolution of basaltic glass in order to obtain energy and nutrients (Thorseth et al., 1995a,b; Furnes et al., 2001; Staudigel et al., 2008b). Endolithic microborings in basaltic glass have been shown to be more abundant in systems where basaltic glass has interacted with marine waters rather than fresh water alone, possibly indicating that marine-like fluids are required by the tubule-forming biota (Cousins et al., 2009). Observations of seafloor samples and experimental studies, have demonstrated that the timescales over which tubular structures are formed are likely to be very long (Staudigel et al., 2008b) and experimental demonstration of tubule formation has not yet been made, although biological etching which may represent incipient tubule formation has been demonstrated (e.g., Staudigel et al., 1995, 1998; Thorseth et al., 1995a). Characterization of organic materials associated with tubular structures is an alternative approach to establishing their potential biogenicity. Here, we report the detection of protein-bearing organic matter associated with the margins of hollow and partly-mineralized tubular structures in basaltic glass. Previous investigations using similar methods have shown evidence for both aliphatic hydrocarbons and carbonates within tubules in basaltic glass (Benzerara et al., 2007), but both aliphatic hydrocarbons and carbonates can be formed by both abiotic and biological processes. Proteins, in contrast, are only known to form via biological activity; therefore, their association with the margins of tubular bioalteration structures would support the origin of the textures through biologically-mediated glass dissolution processes.

\section{MATERIALS AND METHODS}

\section{Sample Provenance and Petrographic Characterization}

The sample used in this study was recovered by the Integrated Ocean Drilling Program during leg 192 from Hole 1184A located at a water depth of $1661.1 \mathrm{~m}$ on the eastern lobe of the OntongJava Plateau (OJP) (Mahoney et al., 2001; Fitton et al., 2004). The sample is a volcaniclastic tuff consisting of ash- to lapilli-sized clasts and vitric shards, accretionary lapilli, armored lapilli, and crystal fragments (pyroxene and plagioclase) in a matrix of finegrained vitric and lithic ash, clay and other alteration-induced minerals cemented by smectite, analcime, calcite, and to a lesser extent celadonite and zeolites (Figure 1). A petrographic thin section prepared using colloidal $\mathrm{Al}_{2} \mathrm{O}_{3}$ polishing compounds (to avoid contamination with $\mathrm{C}$ from diamond or $\mathrm{SiC}$ ) was examined in transmitted light to identify regions with abundant tubular textures. Optical microscopy was carried out in transmitted and reflected light using Nikon LV100 POL petrographic microscopes equipped with Nikon DS-Ri1 12 Mpixel cameras at the University of Western Ontario and Texas Tech University. The section was subsequently sputter-cleaned using an $\mathrm{Ar}^{+}$beam, then coated with a thin layer $(40 \AA)$ of Ir. Backscattered-electron images of the OJP thin section was collected using a Hitachi S-4300SE/N SEM at the College of Arts \& Sciences Microscopy, Texas Tech University, operating at $10-20 \mathrm{kV}$ and $13 \mathrm{~mm}$ working distance.

A LEO (Zeiss) 1540XB FIB/SEM equipped with $30 \mathrm{keV} \mathrm{Ga}^{+}$ Focused Ion Beam (FIB) was used to cut away a thin foil containing partly-mineralized tubules. The foil was welded to a $\mathrm{Cu}$ sample holder by deposition of Pt. The foil was thinned until electron transparent, $\sim 100 \mathrm{~nm}$, by $\mathrm{Ga}^{+}$FIB milling. No traces of the $\mathrm{Al}_{2} \mathrm{O}_{3}$ polishing compound, epoxy resin, the Pt weld joining the sample holder to the foil, or other contaminants were detected in the FIB foil after preparation, as determined using the EDAX Energy Dispersive X-ray spectrometer on the LEO (Zeiss) 1540XB FIB/SEM. We are therefore confident that our analyses are of endogenic materials and are not detectably affected by contamination. The FIB foil was vacuum-sealed under sterile clean room conditions and transported in a sterile, vacuumsealed sample container for STXM analysis.

\section{Electron Probe Micro-Analysis}

Electron probe micro-analysis (EPMA) was carried out using the Cameca SX100 electron probe microanalyzer operating at $15 \mathrm{kV}$ and $30 \mathrm{nA}$ beam current. Representative areas of the OJP thin section were mapped in for $\mathrm{C}, \mathrm{Ti}, \mathrm{Fe}, \mathrm{Si}, \mathrm{Mg}$, and $\mathrm{Ca}$ to determine the distribution of these elements and guide extraction of the FIB foil for STXM analysis. Counting times were $20 \mathrm{~s}$ on peak and $10 \mathrm{~s}$ on background. Natural and synthetic standards were used to refine X-ray peak position. Standards were as follows: $\alpha$-SiC for $\mathrm{C}$; ilmenite for $\mathrm{Ti}$; hematite for $\mathrm{Fe}$; diopside for $\mathrm{Si}$ and $\mathrm{Ca}$; olivine $\left(\mathrm{Fog}_{93}\right)$ for $\mathrm{Mg}$. All EPMA data were corrected using a $\varphi(\rho z)$ routine supplied by the manufacturer. Quantitative element distribution maps of a representative area are shown in Figure 2.

\section{Scanning Transmission X-Ray Microscopy Analysis}

$\mathrm{X}$-ray imaging and spectromicroscopy was carried out at the Canadian Light Source using the STXM microscope on the SM beamline (10D-1) (Kaznatcheev et al., 2007). The absorption edges examined were the $\mathrm{C}$ and $\mathrm{N}$ K-edges, and the $\mathrm{Ti}, \mathrm{Fe}$, and 


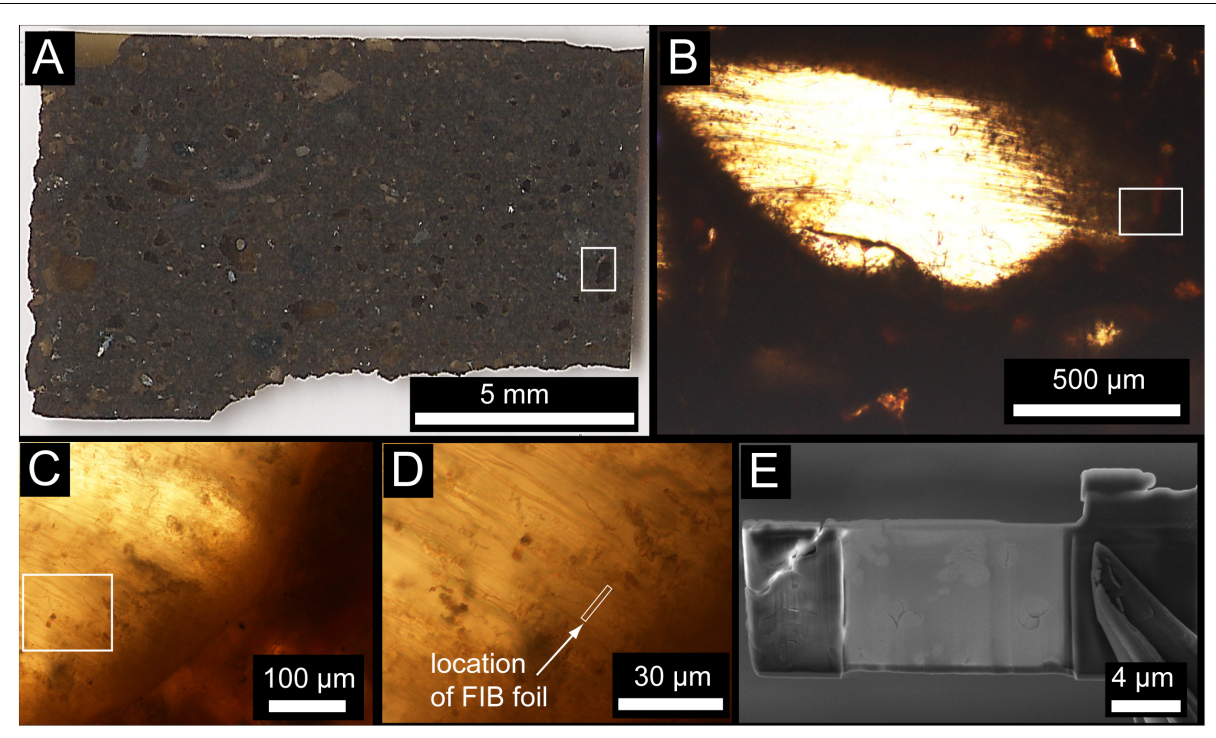

FIGURE 1 | (A) Transmitted light image of the entire Ontong Java Plateau (OJP) petrographic thin section. (B) Example of a little-altered vitric clast containing abundant tubular bioalteration textures. Flattening during compaction of the volcanic pile may be responsible for some of the preferred orientation of bioalteration textures. (C) Enlargement near the margin of the clast in (B) showing tubular textures concentrated near the edge of the clast and projecting into the interior unaltered glass. (D) High-magnification image showing the location of the FIB foil, approximately perpendicular the trend of the tubular textures. (E) Electron microscope image of the FIB foil after extraction and thinning.
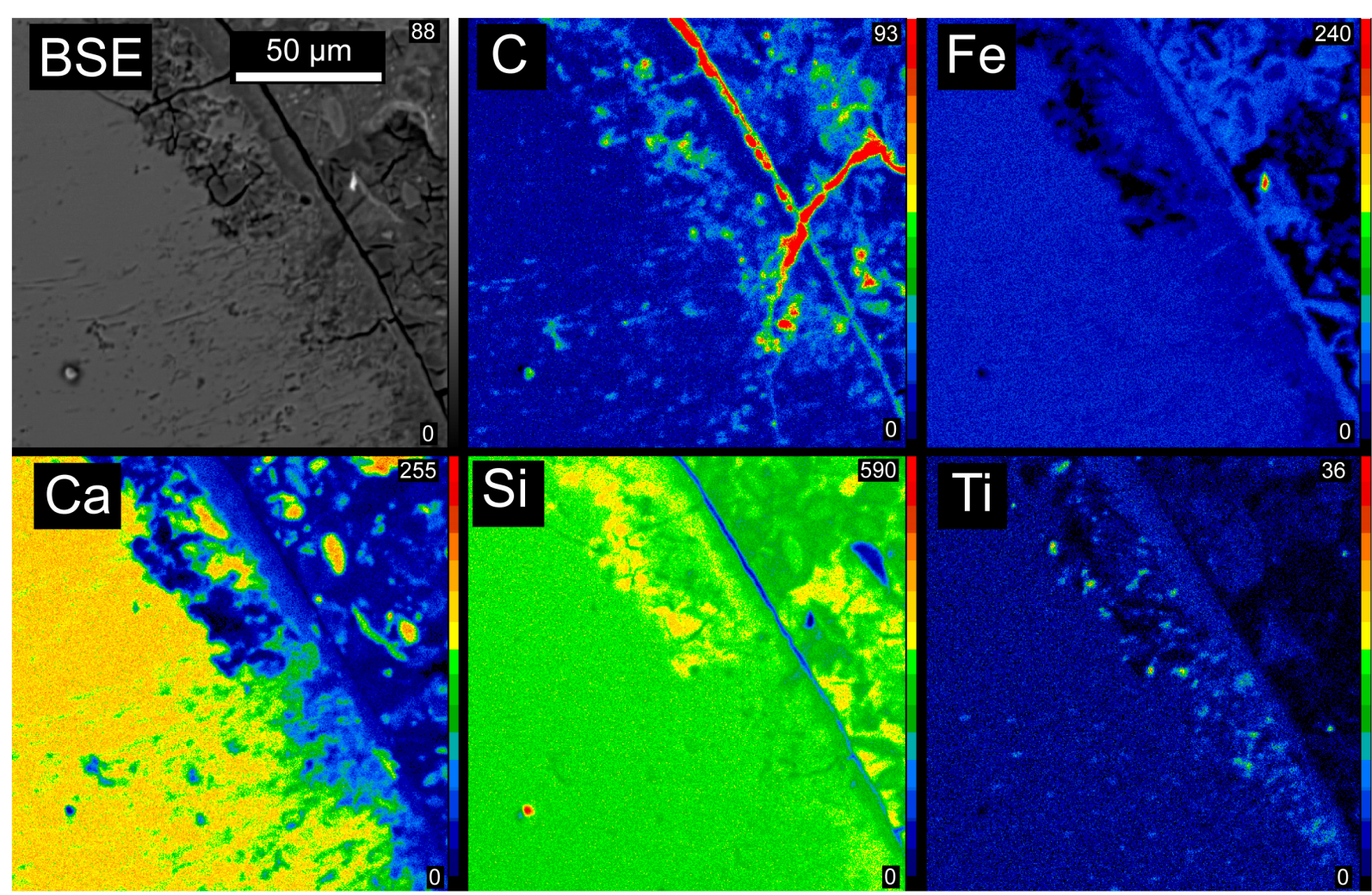

FIGURE 2 | Electron microprobe backscattered electron image and element maps showing the distribution of $\mathrm{C}, \mathrm{Fe}, \mathrm{Ca}$, $\mathrm{Si}$, and Ti in a representative area of the OJP sample. Carbon and $\mathrm{Ti}$ are both associated with tubular textures, visible as thin lines in the BSE image trending approximately perpendicular to the shard boundary into unaltered glass. Very high concentrations of carbon are located outside the glass shards, but these are highly susceptible to contamination and were not studied here for that reason. 

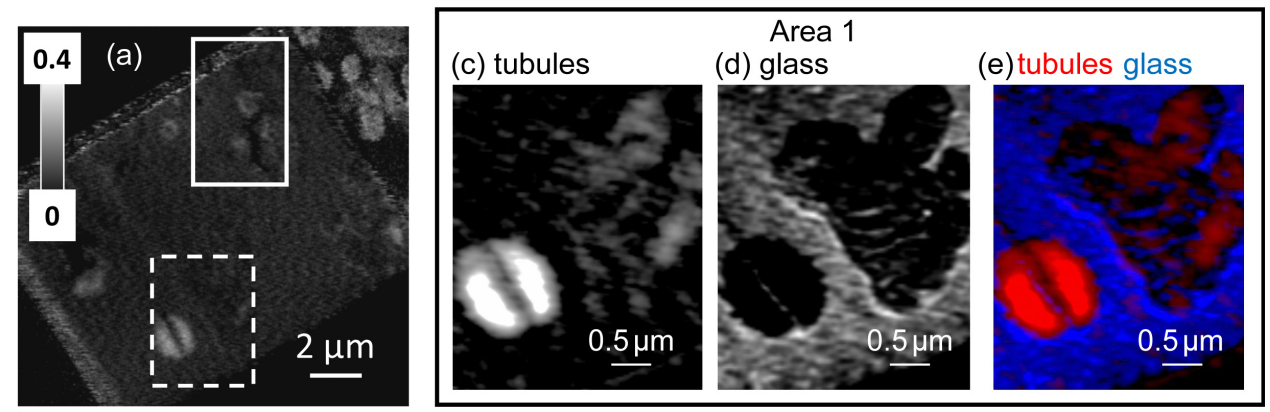

(b) N K-edge spectra
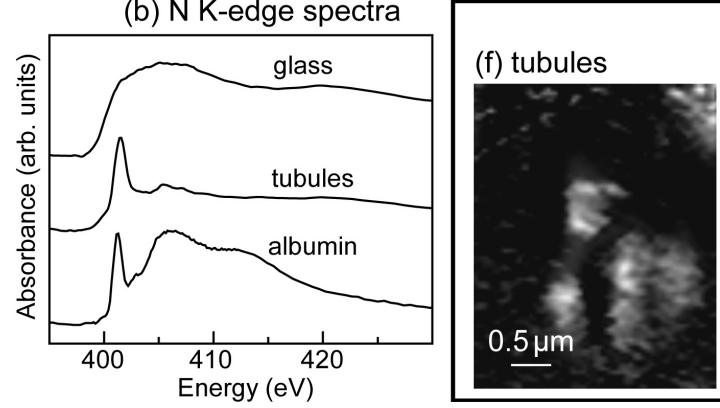

Area 2

(g) glass

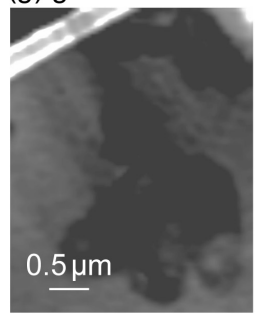

(h) tubules glass

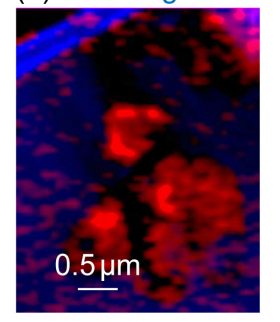

FIGURE 3 | Nitrogen K-edge results. (a) N image difference map $\left(\mathrm{OD}_{401.4}-\mathrm{OD}_{395}\right)$ of the entire FIB section. The dashed white rectangle (Area 1) and the solid white rectangle (Area 2) show the areas from the FIB section where the metal speciation and organics were studied in detail. The gray scale indicates optical density (OD). (b) N K-edge X-ray absorption spectrum of albumin (protein) compared to spectra derived by threshold masking of the high-intensity pixels from the tubule-filling material and glass from Area 1. Areas 1 and 2 component maps: (c,f) tubules, (d,g), glass and color-coded (rescaled) overlays (e,h) of the component maps (tubules $=$ red, glass $=$ blue). The maps were derived by singular value decomposition (SVD) of the image sequences (395-430 eV).

Ca L-edges. On- and off-resonance images were collected of the entire FIB section for each edge; the difference of optical density (OD) images mapped the distribution of the element in the FIB section (Kaznatcheev et al., 2007). The as-measured transmitted on- and off-resonance images and the image sequences were converted to $\mathrm{OD}$, absorbance) using the incidence flux $\left(\mathrm{I}_{0}\right)$ directly from the beam. The organic material, was mapped from the difference in OD images at $288.2 \mathrm{eV}$ (peak of the $\mathrm{C} 1 \mathrm{~s}$ $\pi^{*} \mathrm{C}=\mathrm{O}$ of protein) and $280 \mathrm{eV}$ (prior to the onset of the $\mathrm{C}$ $\mathrm{K}$-edge absorption signal). The difference in the OD images at $352.6 \mathrm{eV}$ (Ca 2 $\mathrm{p}_{1 / 2} \mathrm{Ca} 3 \mathrm{~d}$ resonance) and at $350.2 \mathrm{eV}$ (in the dip between the $2 \mathrm{p}_{3 / 2}$ and $2 \mathrm{p}_{1 / 2}$ resonances) mapped the $\mathrm{Ca}^{2+}$ in the FIB section. The Fe image difference map was derived from the $710 \mathrm{eV}\left(\mathrm{Fe}^{3+} 2 \mathrm{p}_{3 / 2}\right.$ resonance) and $700 \mathrm{eV}$ (prior to the onset of the Fe L-edge absorption signal). The $455 \mathrm{eV}$ image (prior to the onset of the Ti L-edge absorption signal) was subtracted from the $460 \mathrm{eV}$ image to prepare the $\mathrm{Ti}$ image difference map. The $\mathrm{N}$ image difference map was from the difference of the $401.4 \mathrm{eV}$ ( $\pi^{*}$ resonance) image and the $395 \mathrm{eV}$ image (prior to the onset of the $\mathrm{N}$ K-edge absorption signal). Image sequences (i.e., stacks) were collected on two areas we selected, 1 and 2 , and spectral fitting of these stacks with linear combination of reference spectra using singular value decomposition (SVD) (Koprinarov et al., 2002) mapped the element distribution and chemical speciation in the tubule-filling materials and of the glass. Note that when Areas 1 and 2 were fit with K, aragonite, lipid and protein reference spectra, the lipid and protein component maps were different when they were both included in the fit (data not shown). If we only included either protein or lipid in the fit, the component maps were similar. Hence, we choose to only show the protein component map but have referred to it as organic. All image and spectral processing was performed with aXis 2000 (Hitchcock, 1997-2016).

\section{Reference Compounds}

The reference compounds used in the SVD spectral fitting were human serum albumin (protein), xanthan gum (polysaccharide), 1-Palmitoyl-2-hydroxy-sn-glycero-3-phosphocholine (lipid), K (derived by subtracting an appropriately weighted spectrum of $\mathrm{CaCO}_{3}$ from that of $\left.\mathrm{K}_{2} \mathrm{CO}_{3}\right)$, aragonite $\left(\mathrm{CaCO}_{3}\right), \mathrm{FeCl}_{3} \cdot 6 \mathrm{H}_{2} \mathrm{O}$, $\mathrm{FeCl}_{2} \cdot 4 \mathrm{H}_{2} \mathrm{O}$, anatase $\left(\beta-\mathrm{TiO}_{2}\right)$, and $\mathrm{Ca}$ adsorbed to extracellular polymeric substances (EPS). All these STXM NEXAFS reference spectra have been reported previously (Koprinarov et al., 2002; Dynes et al., 2006a,b; Kaznatcheev et al., 2007; Obst et al., 2009) except for anatase. The anatase reference spectrum was collected on the 10ID-1 beamline at the Canadian Light Source by Jian Wang. The anatase was slurried in water and deposited onto a silicon nitride window, and air-dried. All compounds were from Sigma-Aldrich except human serum albumin (Behringwerke AG), lipid (Avanti Polar) and aragonite (School of Geography and Earth Sciences, McMaster University, Hamilton, ON, Canada) and were of a minimum purity of $98 \%$.

\section{RESULTS}

The Ontong Java Plateau (OJP) sample investigated in this study was recovered by Ocean Drilling Program (ODP) leg 

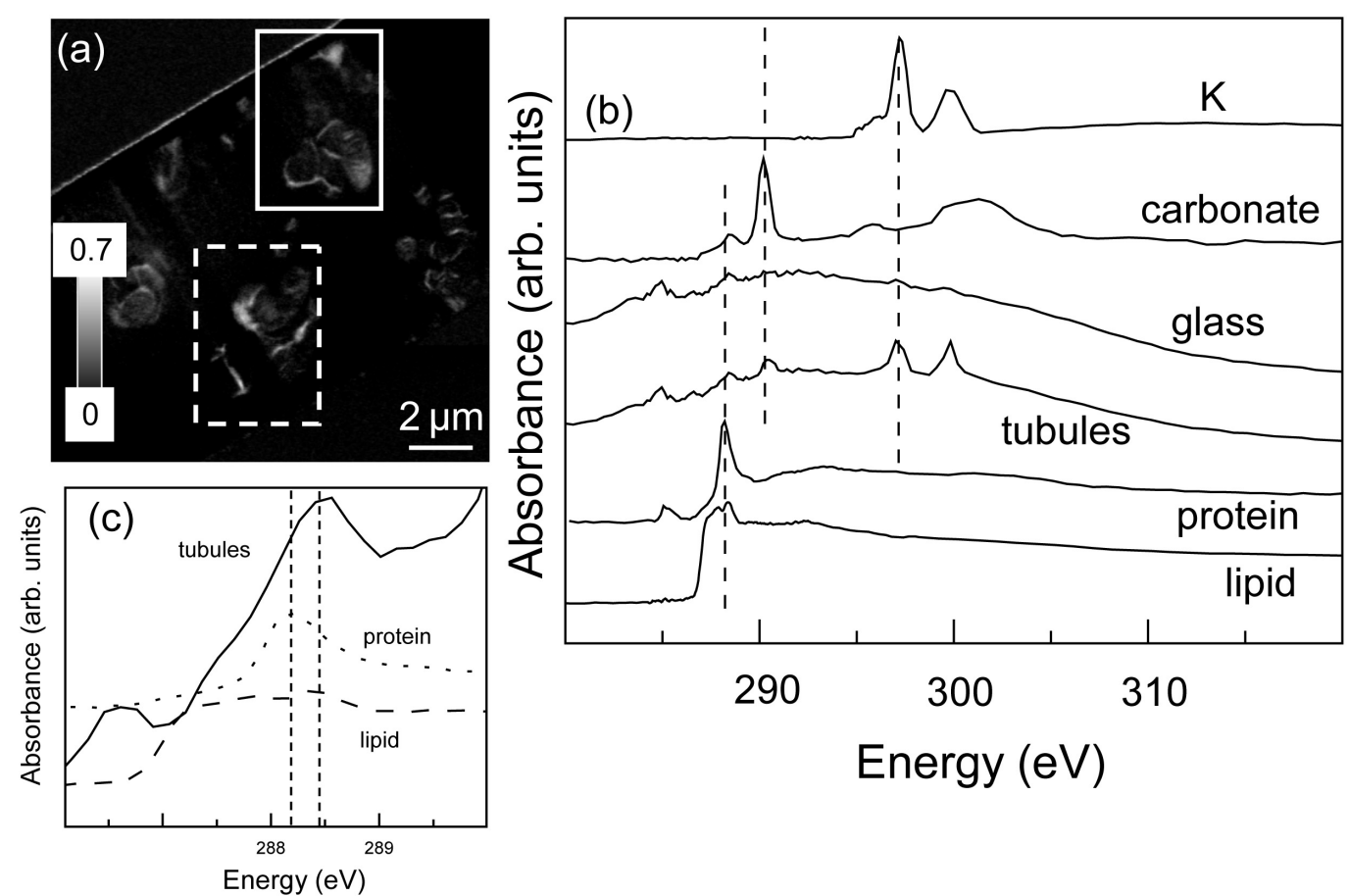

Energy (eV)

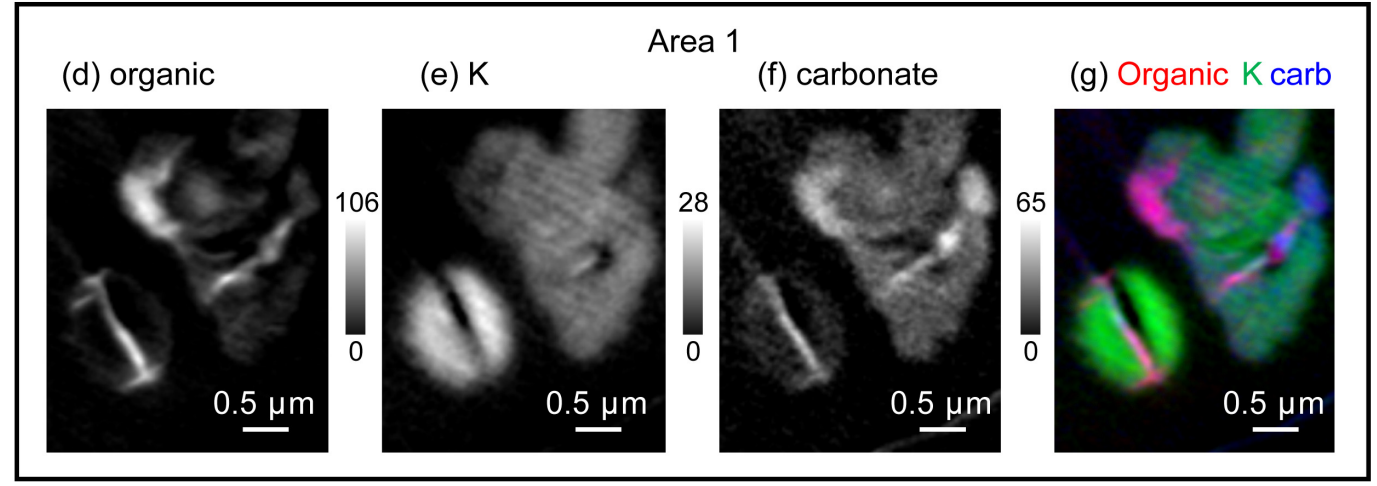

(h) organic

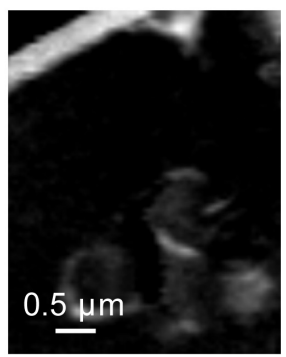

(i) $\mathrm{K}$

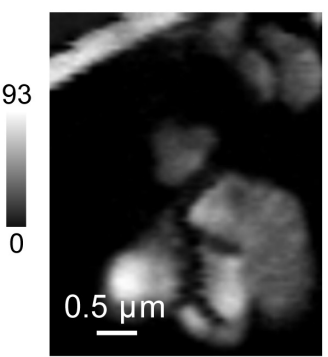

Area 2

(j) carbonate

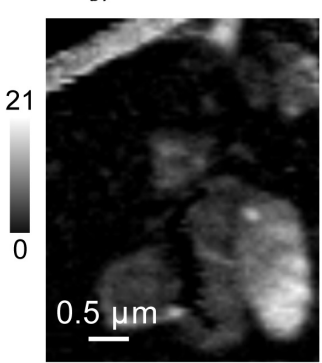

(k) Organic K carb

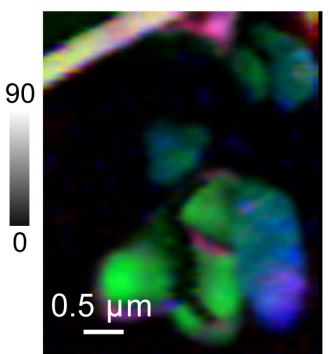

FIGURE 4 | Carbon K-edge results. (a) Total C image difference map $\left(\mathrm{OD}_{288.2}-\mathrm{OD}_{280.0}\right)$ of the entire FIB section. The dashed white rectangle (Area 1) and the solid white rectangle (Area 2) show the areas from the FIB section where the metal speciation and organics were studied in detail. (b) C K-edge X-ray absorption spectra of albumin (protein), 1-Palmitoyl-2-hydroxy-sn-glycero-3-phosphocholine (lipid), aragonite $\left(\mathrm{CaCO}_{3}\right), \mathrm{K}$ compared to spectra derived by threshold masking of the high-intensity pixels of the tubule-filling material and the glass from Area 1. (c) Expanded scale of an overlay of the spectra from the tubule-filling material and reference compounds, showing the presence of both protein and lipid. Area 1 and 2 component maps (d,h) organic (see methods summary for details), (e,i) K, and (f,j) carbonate and the color-coded (rescaled) overlays of the composite maps (organic $=$ red, $\mathrm{K}=$ green, and carbonate $=$ blue). The gray scales of the component

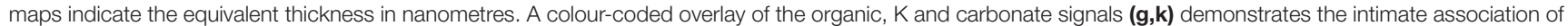
these materials within the tubule-filling material. 

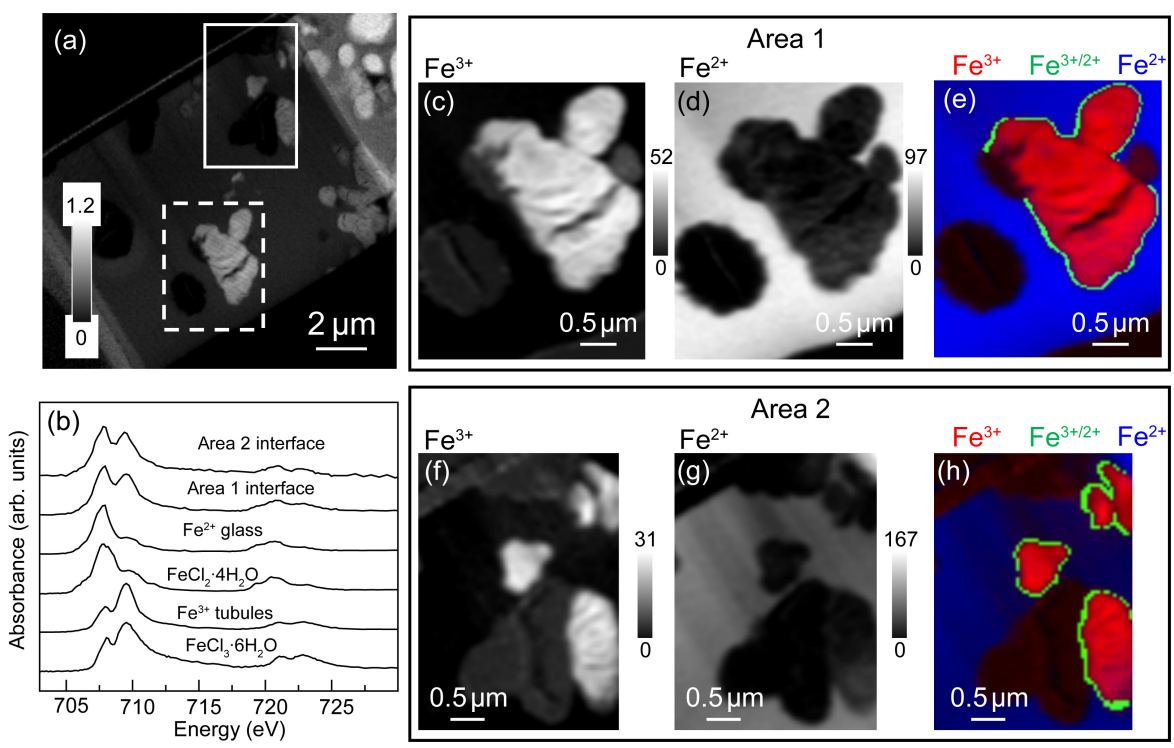

FIGURE 5 | Iron L-edge spectra. (a) Fe image difference map $\left(\mathrm{OD}_{710}-\mathrm{OD}_{700}\right)$ of the entire FIB section. The dashed white rectangle (Area 1) and the solid white rectangle (Area 2) show the areas from the FIB section where the metal speciation and organics were studied in detail. The gray scale indicates optical density. (b) Fe L-edge X-ray absorption spectra of $\mathrm{FeCl}_{3} \cdot 6 \mathrm{H}_{2} \mathrm{O}$ and $\mathrm{FeCl}_{2} \cdot 4 \mathrm{H}_{2} \mathrm{O}$ compared to spectra derived by threshold masking of high-intensity pixels glass and tubule-filling material in Area 1, and from the interface between the tubules and glass for Areas 1 and 2. Areas 1 and 2 component maps (c,f) Fe ${ }^{3+}$, and (d,g) Fe ${ }^{2+}$ and (e,h) color-coded (re-scaled) overlays of the composite maps $\left(\mathrm{Fe}^{3+}=\right.$ red, interface $=$ green and $\mathrm{Fe}^{2+}=$ blue. The gray scale of the component maps indicates equivalent thickness in nanometers.

192 from hole $1184 \mathrm{~A}$ located at a water depth of $1661.1 \mathrm{~m}$ on the eastern lobe of the OJP (Mahoney et al., 2001). The sample is a volcaniclastic tuff, consisting of ash- to lapillisized clasts and vitric shards, accretionary lapilli, armored lapilli, and crystal fragments (pyroxene and plagioclase) in a matrix of fine-grained vitric and lithic ash, clay, and other alteration minerals cemented by smectite, analcime, calcite, rare celadonite, and several zeolites (Figure 1). Coarsely crystalline zeolites, including chabazite and phillipsite, occur sparsely as vug fillings, some of which are concentrically zoned. The sample was previously described in detail by Banerjee and Muehlenbachs (2003), and further studied by Izawa et al. (2010a). Electron microprobe maps (Figure 2) reveal that carbon and titanium are both associated with tubular textures within glass shards. Very high concentrations of carbon are located outside the glass shards, and could reflect a mixture of secondary carbonate precipitation and sedimentary organic matter.

Scanning Transmission X-ray Microscopy X-ray Absorption Near-Edge Spectroscopy (STXM-XANES) allows compositional analysis with sub-micron spatial resolution, and is capable of distinguishing the subtle differences in absorption edge energy structures due to differing bonding environments. An earlier study using a similar approach identified both carbonates and organic matter associated with tubular textures, but more specific identification of the organic constituents was not achieved (Benzerara et al., 2007). In the current study, spectromicroscopy of ultrathin (electron transparent, $\sim 100 \mathrm{~nm}$ ) Focused Ion Beam (FIB) sections through basaltic glass containing tubular textures revealed concentrations of protein-bearing organic matter associated with tubular textures and commonly concentrated at the margins of such tubules.

The total $\mathrm{N}$ map of the FIB section is shown in Figure 3a. In Areas 1 and 2, $\mathrm{N}$ was mapped with spectra extracted from unaltered glass and tubule-filling materials (Figure $3 \mathbf{b}$ ). The $\mathrm{N}$ spectrum extracted from the tubule-filling materials was similar to that of albumin (Figure 3b) and other amide and amine compounds, and showed distinct features near $401.4 \mathrm{eV}$ due to $\pi^{*}$ resonances, while the $\mathrm{N}$ spectrum extracted from the glass had a broad peak about $405.2 \mathrm{eV}$, attributed to $1 \mathrm{~s} \rightarrow$ $\sigma^{*}$ transitions (Leinweber et al., 2007), demonstrating that the tubule-filling materials likely contain protein (Figures $\mathbf{3 c}-\mathbf{h}$ ). Carbon is much more abundant within tubule-filling alteration assemblages than in the surrounding basaltic glass (Figure 4a). Comparison between measured and reference spectra showed that concentrations of organics, carbonate, and $\mathrm{K}$ were higher in tubule-filling materials (Figure $\mathbf{4 b}$ ). For the organics, the characteristic peak of the $\mathrm{C} 1 \mathrm{~s} \rightarrow \pi^{*} \mathrm{C}-\mathrm{OH}$ transition at around $289.5 \mathrm{eV}$ was not apparent, indicating that the tubules did not contain abundant polysaccharides (Figure $4 \mathbf{b}$ ). All proteins have a characteristic sharp peak at $288.2 \mathrm{eV}$ due to the $\mathrm{C} 1 \mathrm{~s}$ $\rightarrow \pi^{*}$ CONH transition of peptide bonds (Leung et al., 2010), and in bacteria this peak is very apparent (Dynes et al., 2009). Lipids contain carboxylic groups, and have a broad characteristic peak from about 287 to $288 \mathrm{eV}$ due to the $\mathrm{C} 1 \mathrm{~s} \rightarrow \pi^{*} \mathrm{COOH}$ transition (Lawrence et al., 2003). Spectra extracted from the tubules are consistent with the presence of both lipids and proteins (Figure 4c). Spectra of glass and tubule-filling materials are similar in the region of lipid and protein resonances $(\sim 288-$ $289 \mathrm{eV})$, but the intensity of the signal from the organic 

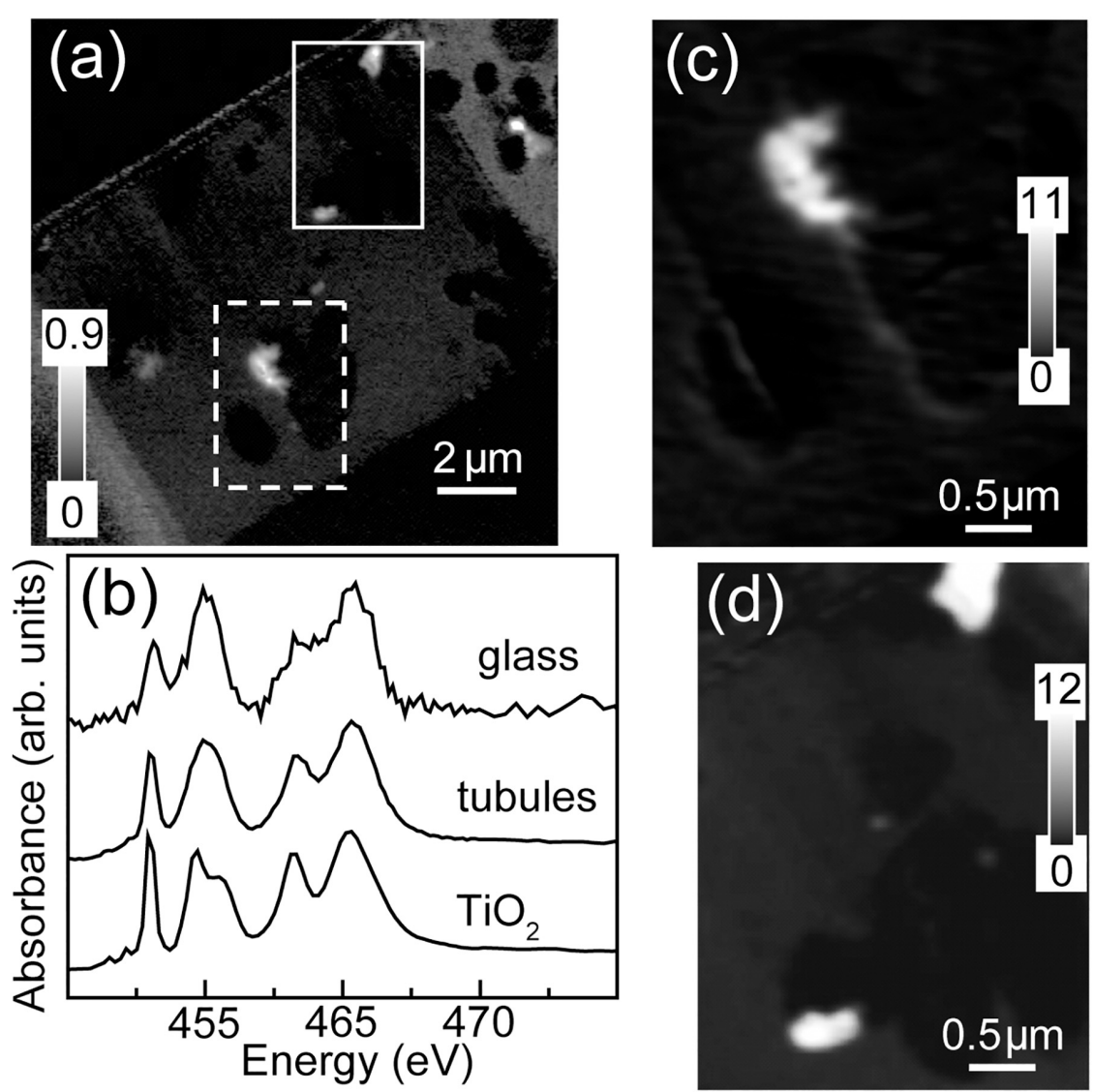

FIGURE 6 | Titanium L-edge spectra. (a) Ti image difference map $\left(\mathrm{OD}_{460}-\mathrm{OD}_{455}\right)$ of the entire FIB section. The dashed white rectangle (Area 1) and the solid white rectangle (Area 2) show the areas from the FIB section where the metal speciation and organics were studied in detail. The gray scale indicates optical density. (b) Ti L-edge $\mathrm{X}$-ray absorption spectra of anatase $\left(\beta-\mathrm{TiO}_{2}\right)$ compared to the spectra derived by threshold masking of high-intensity pixels of the tubule-filling material and glass from Area 1. Ti component maps (c) Area 1 and (d) Area 2. The gray scales for the component maps indicate equivalent thickness in nanometers.

resonances is much stronger in the regions interpreted here as containing protein- and- lipid-bearing organic matter (bright regions of Figure 4d). Mapping of smaller regions of interest (Figures 4d-k) shows the heterogeneous distribution of organic matter as well as inorganic carbonate and potassium (likely a component of phyllosilicate minerals).

The total iron (Fe) map of the FIB section is shown in Figure 5. Both the tubule-filling materials and the surrounding basaltic glass contained $\mathrm{Fe}$. The oxidation state of the $\mathrm{Fe}$ in the tubules and bulk was determined by fitting of the Fe 2p stack with the $\mathrm{FeCl}_{3} \cdot 6 \mathrm{H}_{2} \mathrm{O}$ and $\mathrm{FeCl}_{2} \cdot 4 \mathrm{H}_{2} \mathrm{O}$ reference spectra (Figure 5b). Spectra derived by threshold masking of the high intensity pixels from the component maps (Figure $5 \mathbf{b}$ ) confirmed that the $\mathrm{Fe}$ in the tubules was predominantly $\mathrm{Fe}^{3+}$ (Figures $\mathbf{5 c}, \mathbf{f}$ ), while that in the glass was $\mathrm{Fe}^{2+}$ (Figures 5d,g). The spectra extracted from the narrow ( 50 to $100 \mathrm{~nm}$ thick) interface between the unaltered glass and the tubule-filling materials showed that the oxidation state of the Fe was mixed (Figure 5b). Most of the tubule-filling materials are similar to palagonite, a common alteration product of basaltic glass consisting of a mixture of poorly-crystalline Fe-oxyhydroxides, phyllosilicates, and zeolites (Stroncik and Schmincke, 2002).
The total Ti map of the FIB section is shown in Figure 6. Titanium is concentrated in small ( $\sim$ few $100 \mathrm{~nm}$ ), irregularlyshaped particles, always within the altered material inside tubules. Spectra extracted from the high intensity pixels of the particles in the tubules and of the bulk, by threshold masking, confirmed that the particles are anatase $\left(\beta-\mathrm{TiO}_{2}\right)$ (Figures 6c,d) (Liu et al., 2010).

The total Ca map of the FIB section is shown in Figure 7. Calcium is abundant in the unaltered basaltic glass and very low in most of the tubule-filling materials. Spectra extracted from the high intensity pixels of the glass and from the material in the tubules, by threshold masking of the component map (Figures 7b,d), showed that these spectra were similar to each other and to that of $\mathrm{CaHPO}_{4} \cdot 2 \mathrm{H}_{2} \mathrm{O}$ and $\mathrm{Ca}$ adsorbed to microbial exopolymeric substances (Lawrence et al., 2003); they are clearly not consistent with crystalline calcite $\left(\mathrm{CaCO}_{3}\right)$ (Figure 7c).

\section{DISCUSSION}

The N and C STXM-XANES spectra demonstrate the presence of proteins and lipids within the partially mineralized tubular textures. Protein-bearing organic matter is particularly associated 

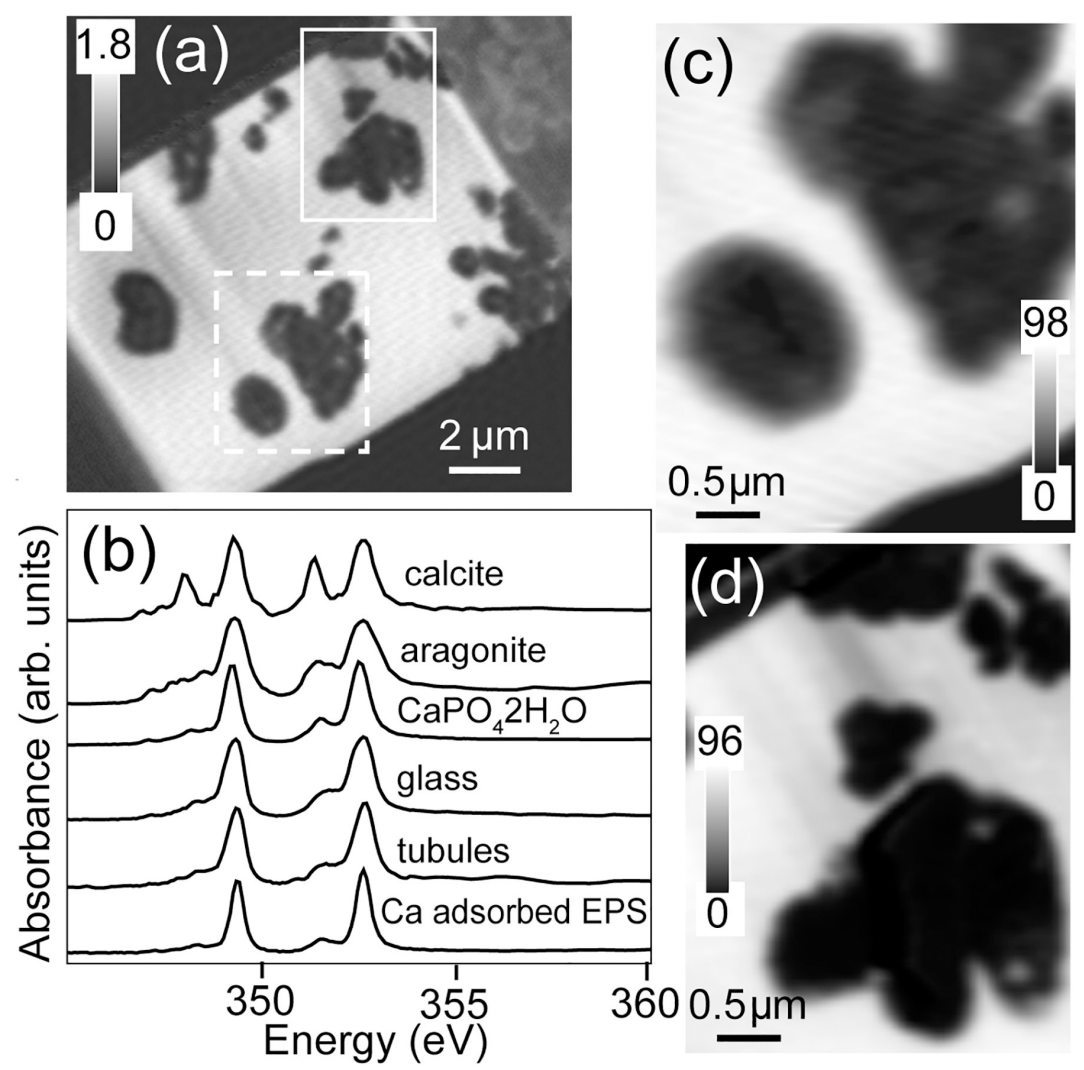

FIGURE 7 | Calcium L-edge spectra. (a) Ca image difference map $\left(\mathrm{OD}_{352.6}-\mathrm{OD}_{350.6}\right)$ of the entire FIB section. The dashed white rectangle (Area 1) and the solid white rectangle (Area 2) show the areas from the FIB section where the metal speciation and organics were studied in detail. The gray scale indicates optical density. (b) $\mathrm{Ca}$ L-edge X-ray absorption spectra of calcite $\left(\mathrm{CaCO}_{3}\right)$, aragonite $\left(\mathrm{CaCO}_{3}\right), \mathrm{CaHPO}_{4} \cdot 2 \mathrm{H}_{2} \mathrm{O}$ and Ca adsorbed on exopolysaccharides (EPSs) compared to the spectrum derived by threshold masking of the high-intensity pixels of the tubule-filling material and glass of Area 1. Ca component maps of (c) Area 1 and (d) Area 2. The gray scales of the component maps indicate equivalent thickness in nanometers.

with the interfaces between unaltered basaltic glass and alteration products, consistent with the preservation of cellular remnants derived from microbes that had colonized and etched the glass. The association of protein- and lipid-bearing organic matter with the margins of tubules is as expected if the tubules formed via microbial glass dissolution and the proteins and other organic matter represent fossil cellular material (cell envelope remnants and extracellular materials). Tubule-filling materials also include phyllosilicate-rich material dominated by $\mathrm{Fe}^{3+}$ (likely palagonite) and Ti-rich particles with mixed $\mathrm{Fe}^{3+}$ and $\mathrm{Fe}^{2+}$; the surrounding basaltic glass is $\mathrm{Fe}^{2+}$-dominated. Boundaries between unaltered glass and alteration materials commonly contain a mixture of $\mathrm{Fe}$ valence states, providing direct support to previous suggestions (Thorseth et al., 1995b; Torsvik et al., 1998) that biologically-mediated Fe-oxidation plays an important role in microbial dissolution of basaltic glass. Ti-rich materials within tubular microtextures are potential nucleation sites for the later growth of titanite, pointing to a mechanism for the preservation of these trace fossils through geologic time. Our observations support both the biogenicity of tubular microtextures in basaltic glass and a direct correspondence between bioalteration in modern oceanic crust and ancient mineralized tubules thought to constitute the one of the oldest presently-known microfossils. Previous studies using confocal microscopy and fluorescent staining with ethidium bromide have demonstrated a likely association of nucleic acids with tubule walls (Banerjee and Muehlenbachs, 2003); however, some doubts have remained due to the possible roles of non-specific binding, capillary action, and possible contamination. In the present study, proteins associated with tubular textures in basaltic glass have been directly detected using STXM, providing independent confirmation of previous observations of biological macromolecules, i.e., nucleic acids (e.g., Banerjee and Muehlenbachs, 2003). While contamination can never be completely ruled out, the intimate association of biological material with the margins of tubular microtunnels in basaltic glass strongly supports the interpretation of the tubules as ichnofossils.

The tubule-filling materials also contain Ti-rich particles (Figure 6) in close contact with protein-rich organic matter (Figures 4a,d,h). Previous studies have shown that Ti-rich materials exist within altered basaltic glass (Zhou and Fyfe, 1989), and titanite has been detected along tubule-rich rims of basaltic glass shards, including the one studied here (Izawa et al., 2010a), 
but in situ identification of titanite or precursor material(s) within tubular structures has been lacking. The presence of $\mathrm{TiO}_{2}$ rich materials within tubules has important implications for the preservation of these textures in basaltic glass through geologic time. Titanite-mineralized tubular textures are widely reported in ancient, metamorphosed basaltic glasses, and have been interpreted as trace fossils (e.g., Furnes and Muehlenbachs, 2003; Furnes et al., 2004; Banerjee et al., 2006; Staudigel et al., 2008a). Calcium is also abundant in the unaltered basaltic glass and very low in the tubule-filling materials; however, it is notable that the Ti-rich particles have a slightly higher Ca concentration than the tubule-filling palagonite, as this suggests a prime environment for titanite formation (Figures 6, 7). Moreover, $\mathrm{Ca}^{2+}$ is expected to be abundant in the solutions (seawater and hydrothermal) present during the alteration of subaqueous basaltic rocks.

We suggest that titanite-mineralized tubules in ancient metamorphosed basaltic glass are trace fossils (for contrary views see, e.g., Lepot et al., 2011; Grosch and McLoughlin, 2014). Titanium is normally a highly immobile element, so the presence of $\mathrm{Ti}$ compounds within tubular bioalteration structures might simply reflect passive accumulation: as the surrounding glass is dissolved, Ti remains and rapidly forms nanoscale oxide particles such as those observed here (e.g., Banerjee and Muehlenbachs, 2003; Staudigel et al., 2006; Izawa et al., 2010a). Regardless of how they are formed, Ti-rich particles within tubular structures can then act as growth nuclei for later-formed metamorphic titanite, which would explain why titanite mineralization is commonly observed to be strongly concentrated in microbial alteration textures (e.g., Furnes et al., 2004; Staudigel et al., 2006). Detection of Ti-rich materials here demonstrates that precursor materials for metamorphic titanite growth occur within partly mineralized tubules on the seafloor, demonstrating a direct link between modern tubular bioalteration textures in seafloor glasses and the oldest-known microbial trace fossils.

\section{CONCLUSION}

- X-ray spectromicroscopic observations have revealed that microtubules within basaltic glass contain biomolecular traces of life in the form of proteins and lipids.

- The tubule-filling materials are dominated by $\mathrm{Fe}^{3+}$ while the unaltered glass is dominated by $\mathrm{Fe}^{2+}$, and there may be a preserved transition zone with mixed Fe valance. These

\section{REFERENCES}

Banerjee, N. R., Furnes, H., Muehlenbachs, K., Staudigel, H., and de Wit, M. (2006). Preservation of $\sim 3.4-3.5$ Ga microbial biomarkers in pillow lavas and hyaloclastites from the Barberton Greenstone Belt, South Africa. Earth Planet. Sci. Lett. 241, 707-722. doi: 10.1016/j.epsl.2005.11.011

Banerjee, N. R., and Muehlenbachs, K. (2003). Tuff life: bioalteration in volcaniclastic rocks from the Ontong Java Plateau. Geochem. Geophys. Geosyst. 4, 1037-1059.

Banerjee, N. R., Simonetti, A., Furnes, H., Muehlenbachs, K., Staudigel, H., Heaman, L., et al. (2007). Direct dating of Archean microbial ichnofossils. Geology 35, 487-490. observations are consistent with (although not diagnostic of) a role for microbially mediated Fe oxidation during the formation of the tubular structures.

- Preserved biomaterials are closely associated with alteration material and with $\mathrm{TiO}_{2}$-rich particles, demonstrating a high preservation potential for elemental, biochemical, and textural signatures of microbial activity during basaltic glass alteration.

- These results provide strong confirmation of previous results that suggested the presence of biomolecular remnants associated with tubular alteration structures in basaltic glass.

- The overall weathering and bioalteration process that have affected these basaltic glass samples have preserved both protein and lipid as biomarkers at the microbe-mineral interface.

\section{AUTHOR CONTRIBUTIONS}

MI designed the research, analyzed the results, and wrote the manuscript. NB, RF, and GS helped to design the research. JD, LM, and MI performed the STXM measurements and analyzed the STXM data. SM and MI carried out the EPMA analysis. CH performed the optical and electron-beam imaging and assisted in data analysis. All authors discussed the results and commented on the manuscript.

\section{FUNDING}

MI acknowledges funding from the Natural Sciences and Engineering Research Council of Canada (NSERC), Mineralogical Association of Canada, Canada IODP, and the Canadian Astrobiology Training Program. NB, RF, and GS acknowledge funding from the NSERC.

\section{ACKNOWLEDGMENTS}

We thank the crew, technicians, and science party of ODP Leg 192 aboard the drill ship JOIDES Resolution. Our thanks are also due to T. Simpson for preparing the FIB sample and to J. Wang for the anatase STXM NEXAFS reference spectrum.

Benzerara, K., Menguy, N., Banerjee, N. R., Tyliszczak, T., Brown, G. E., and Guyot, F. (2007). Alteration of submarine basaltic glass from the Ontong Java Plateau: a STXM and TEM study. Earth Planet. Sci. Lett. 260, 187-200. doi: 10.1016/j.epsl.2007.05.029

Cousins, C. R., Smellie, J. L., Jones, A. P., and Crawford, I. A. (2009). A comparative study of endolithic microborings in basaltic lavas from a transitional subglacial-marine environment. Int. J. Astrobiol. 8, 37-49. doi: $10.1017 / \mathrm{s} 1473550408004369$

Dynes, J. J., Lawrence, J. R., Korber, D. R., Swerhone, G. D. W., Leppard, G. G., and Hitchcock, A. P. (2006a). Quantitative mapping of chlorhexidine in natural river biofilms. Sci. Total Environ. 369, 369-383. doi: 10.1016/j.scitotenv.2006. 04.033 
Dynes, J. J., Tyliszczak, T., Araki, T., Lawrence, J. R., Swerhone, G. D. W., Leppard, G. G., et al. (2006b). Speciation and quantitative mapping of metal species in microbial biofilms using scanning transmission X-ray microscopy. Environ. Sci. Technol. 40, 1556-1565. doi: 10.1021/es0513638

Dynes, J. J., Lawrence, J. R., Korber, D. R., Swerhone, G. D. W., Leppard, G. G., and Hitchcock, A. P. (2009). Morphological and biochemical changes in Pseudomonas fluorescens biofilms induced by sub-inhibitory exposure to antimicrobial agents. Can. J. Microbiol. 55, 163-178. doi: 10.1139/w08-109

Fitton, J. G., Mahoney, J. J., Wallace, P. J., and Saunders, A. D. (2004). "Ocean Drilling Program," in Proceedings of the Ocean Drilling Program leg 192. (College Station, TX).

Furnes, H., Banerjee, N. R., Muehlenbachs, K., Staudigel, H., and de Wit, M. (2004). Early life recorded in Archean Pillow Lavas. Science 304, 578-581. doi: 10.1126/science. 1095858

Furnes, H., and Muehlenbachs, K. (2003). "Bioalteration recorded in ophiolitic pillow lavas," in Ophiolites in Earth's History. eds Y. Dilek and P. T. Robinsons (London: Geological Society of London), 415-426. doi: 10.1144/gsl.sp.2003.218. 01.21

Furnes, H., Staudigel, H., Thorseth, I. H., Torsvik, T., Muehlenbachs, K., and Tumyr, O. (2001). Bioalteration of basaltic glass in the oceanic crust. Geochem. Geophys. Geosyst. 2:2000GC000150.

Grosch, E., and McLoughlin, N. (2014). Reassessing the biogenicity of Earth's oldest trace fossil with implications for biosignatures in the search for early life. Proc. Natl. Acad. Sci. U.S.A. 111, 8380-8385. doi: 10.1073/pnas.1402565111

Hitchcock, A. P. (1997-2016). Axis 2000 - Analysis of X-Ray Images and Spectra. McMaster University.

Izawa, M. R. M., Banerjee, N. R., Flemming, R. L., and Bridge, N. J. (2010a). Preservation of microbial ichnofossils in basaltic glass by titanite mineralization. Can. Mineral. 48, 1255-1265. doi: 10.3749/canmin.48.5.1255

Izawa, M. R. M., Banerjee, N. R., Flemming, R. L., Bridge, N. J., and Schultz, C. (2010b). Basaltic glass as a habitat for microbial life: implications for astrobiology and planetary exploration. Planet. Space Sci. 58, 583-591. doi: 10.1016/j.pss.2009.09.014

Jones, B., and Goodbody, Q. H. (1982). The geological significance of endolithic algae in glass. Can. J. Earth Sci. 19, 671-678. doi: 10.1139/e82-056

Kaznatcheev, K. V., Karunakaran, C., Lanke, U. D., Urquhart, S. G., Obst, M., and Hitchcock, A. P. (2007). Soft X-ray spectromicroscopy beamline at the CLS: commissioning results. Nucl. Instrum. Methods Phys. Res. A 582, 96-99. doi: $10.1063 / 1.3491837$

Koprinarov, I. N., Hitchcock, A. P., McCrory, C. T., and Childs, R. F. (2002). Quantitative mapping of structured polymeric systems using singular value decomposition analysis of soft X-ray images. J. Phys. Chem. B 106, 5358-5364. doi: $10.1021 /$ jp0132811

Lawrence, J. R., Swerhone, G. D., Leppard, G. G., Araki, T., Zhang, X., West, M. M., et al. (2003). Scanning transmission X-ray, laser scanning, and transmission electron microscopy mapping of the exopolymeric matrix of microbial biofilms. Appl. Environ. Microbiol. 69, 5543-5554. doi: 10.1128/AEM.69.9.5543-5554. 2003

Leinweber, P., Kruse, J., Walley, F. L., Gillespie, A., Eckhardt, K.-U., Blyth, R. I. R., et al. (2007). Nitrogen K-edge XANES - an overview of reference compounds used to identify 'unknown' organic nitrogen in environmental samples. J. Synchrot. Radiat. 14, 500-511. doi: 10.1107/s0909049507042513

Lepot, K., Benzerara, K., and Philippot, P. (2011). Biogenic versus metamorphic origins of diverse microtubes in $2.7 \mathrm{Gyr}$ old volcanic ashes: multi-scale observations. Earth Planet. Sci. Lett. 312, 37-47. doi: 10.1016/j.epsl.2011.10.016

Leung, B. O., Brash, J. L., and Hitchcock, A. P. (2010). Characterization of biomaterials by soft X-Ray spectromicroscopy. Materials 3, 3911-3938. doi: 10.3390/ma3073911

Liu, L. J., Chan, J., and Sham, T.-K. (2010). Calcination-induced phase transformation and accompanying optical luminescence of $\mathrm{TiO} 2$ nanotubes: an $\mathrm{X}$-ray absorption near-edge structures and X-ray excited optical luminescence study. J. Phys. Chem. C 114, 21353-21359. doi: 10.1021/jp1093355

Mahoney, J. J., Fitton, J. G., Wallace, P. J., Antretter, M. J., Banerjee, N. R., Bergen, J. A., et al. (2001). "Leg 192: basement drilling of the Ontong Java Plateau," in Proceedings of the Ocean Drilling Program, Initial Reports, Ocean Drilling Program. (College Station, TX), 736.

McLoughlin, N., Furnes, H., Banerjee, N. R., Muehlenbachs, K., and Staudigel, H. (2009). Ichnotaxonomy of microbial trace fossils in volcanic glass. J. Geol. Soc. 166, 159-169. doi: 10.1144/0016-76492008-049
McLoughlin, N., Furnes, H., Banerjee, N. R., Staudigel, H., Muehlenbachs, K., de Wit, M., et al. (2008). "Micro-bioerosion in volcanic glass: extending the ichnofossils record to Archean basaltic crust," in Current Developments in Bioerosion. eds M. Wisshak and L. Tapanilas (Heidelberg: Springer-Verlag), 500.

Obst, M., Wang, J., and Hitchcock, A. P. (2009). Soft X-ray spectro-tomography study of cyanobacterial biomineral nucleation. Geobiology 7, 577-591. doi: 10.1111/j.1472-4669.2009.00221.x

Ross, K. A., and Fisher, R. V. (1986). Biogenic grooving on glass shards. Geology 14, 571-573.

Santelli, C. M., Orcutt, B. N., Banning, E. B., Bach, W., Moyer, C. L., Sogin, M. L., et al. (2008). Abundance and diversity of microbial life in ocean crust. Nature 453, 653-657. doi: 10.1038/nature06899

Staudigel, H., Chastain, R. A., Yayanos, A., and Bourcier, R. (1995). Biologically mediated dissolution of glass. Chem. Geol. 126, 119-135.

Staudigel, H., Furnes, H., Banerjee, N. R., Dilek, Y., and Muehlenbachs, K. (2006). Microbes and volcanoes: a tale from the oceans, ophiolites, and greenstone belts. GSA Today 16, 4-10.

Staudigel, H., Furnes, H., McLoughlin, N., Banerjee, N. R., Connel, L. B., and Templeton, A. (2008a). 3.5 billion years of glass bioalteration: volcanic rocks as a basis for microbial life?. Earth Sci. Rev. 89, 156-176. doi: 10.1016/j.earscirev. 2008.04.005

Staudigel, H., Furnes, H., McLoughlin, N., Banerjee, N. R., Connell, L. B., and Templeton, A. (2008b). Microbial glass bioalteration: inferring mechanisms of biocorrosion from trace fossil morphology. Geochim. Cosmochim. Acta 72, A893-A893.

Staudigel, H., Furnes, J., and DeWit, M. (2015). Paleoarchean trace fossils in altered volcanic glass. PNAS 112, 6892-6897. doi: 10.1073/pnas.1421052112

Staudigel, H., and Hart, S. R. (1983). Alteration of basaltic glass: mechanisms and significance for the oceanic crust-seawater budget. Geochim. Cosmochim. Acta 47, 337-350. doi: 10.1016/0016-7037(83)90257-0

Staudigel, H., Yayanos, A., Chastain, R., Davies, G., Th Verdurmen, E. A., Schiffman, P., et al. (1998). Biologically mediated dissolution of volcanic glass in seawater. Earth Planet. Sci. Lett. 164, 233-244. doi: 10.1016/s0012-821x(98) 00207-6

Stroncik, N. A., and Schmincke, H. U. (2002). Palagonite - a review. Int. J. Earth Sci. 91, 680-697. doi: 10.3390/life5010568

Thorseth, I. H., Furnes, H., and Heldal, M. (1992). The importance of microbiological activity in the alteration of natural basaltic glass. Geochim. Cosmochim. Acta 56, 845-850. doi: 10.1016/0016-7037(92)90104-q

Thorseth, I. H., Torsvik, T., Furnes, H., and Muehlenbachs, K. (1995b). Microbes play an important role in the alteration of oceanic crust. Chem. Geol. 126, 137-146. doi: 10.1016/0009-2541(95)00114-8

Thorseth, I. H., Furnes, H., and Tumyr, O. (1995a). Textural and chemical effects of bacterial activity on basaltic glass: an experimental approach. Chem. Geol. 119, 139-160. doi: 10.1016/0009-2541(94) 00098-s

Torsvik, T., Furnes, H., Muehlenbachs, K., Thorseth, I. H., and Tumyr, O. (1998). Evidence for microbial activity at the glass-alteration interface in oceanic basalts. Earth Planet. Sci. Lett. 162, 165-176. doi: 10.1016/s0012-821x(98) 00164-2

Wacey, D., McLoughlin, N., Saunders, M., and Kong, C. (2014). The nano-scale anatomy of a complex carbon-lined microtube in volcanic glass from the 92 Ma Troodos Ophiolite. Cyprus. Chem. Geol. 363, 1-12. doi: 10.1016/j.chemgeo. 2013.10.028

Zhou, Z., and Fyfe, W. S. (1989). Palagonitization of basaltic glass from DSDP Site 335, Leg 37: textures, chemical composition, and mechanism of formation. Am. Mineral. 74, 1045-1053.

Conflict of Interest Statement: The authors declare that the research was conducted in the absence of any commercial or financial relationships that could be construed as a potential conflict of interest.

Copyright (C) 2019 Izawa, Dynes, Banerjee, Flemming, MacLean, Hetherington, Matveev and Southam. This is an open-access article distributed under the terms of the Creative Commons Attribution License (CC BY). The use, distribution or reproduction in other forums is permitted, provided the original author(s) and the copyright owner(s) are credited and that the original publication in this journal is cited, in accordance with accepted academic practice. No use, distribution or reproduction is permitted which does not comply with these terms. 